\title{
New Communication Technologies and Journalism Ethics in Zimbabwe: Practices and
} Malpractices.

\author{
Tendai Chari, University of Venda, South Africa
}

\begin{abstract}
New media technologies have transformed journalism practice in a profound way and Zimbabwe has not been exception. However, research on the impact of these technologies on journalism ethical is troublingly scant. Much of the scholarly attention tends to focus on uses of new media technologies in everyday practice, while their ethical implications are pushed to the backstage. This is in spite of the fact that, the social utility of journalism is largely predicated on its ability to function as a provider of public knowledge, and "truthful, comprehensive and intelligent" accounts of news and events (Ward 2008). The present study examines ethical challenges faced by Zimbabwean journalism practitioners when using the internet, email and cellular phones in their operations. The study combines a survey questionnaire and semi-structured interviews to elicit data on ethical challenges and dilemmas faced journalism practitioners in Zimbabwe.. Results reveal a dialectical impact of new media technologies on journalism and suggest that, the Internet, email and cellular phone are viewed as enhancers as well as obstacles to ethical journalism. The paper motivates for the application of the sociology of journalism ethics as a framework for examining ethical challenges and dilemmas faced by journalism practitioners when using new media technologies. It is argued that the practice of ethical journalism should be viewed as circumscribed by the interaction of a complex web of structural, institutional and socio-economic factors, both internal and external to the environment in which journalism is practiced.
\end{abstract}

Keywords: Ethical Challenges; New Communication Technologies; Journalism ethics; Journalism practice; Sociology of Journalism Ethics; Malpractices. 


\section{Introduction}

The way in which news is conceptualized, gathered, produced, disseminated or consumed is changing in the context of new communication technologies. Earlier research on the impact of new media technologies on journalism practice has tended to focus more on how these technologies have reconfigured news production, dissemination and consumption practices. New media technologies, such as the mobile phone enable journalists to gather news from every nook and cranny of the globe, and send text messages to their newsrooms with relative ease. Others demonstrate how the internet provides media personnel with unlimited access to information on any subject, and how email newsgroups allow journalists to "... tap into the collective brain, wit and wisdom of thousands of knowledgeable journalists and nonjournalists" (Berger, 1997:124).

One limitation of these studies is their tendency to view new media technologies in binary terms; either foregrounding technical enhancements of new media technologies or their negative impact on journalism practice. Fortunati et al., (cited by Bastos et al., (2009:2), notes how on the positive side, the internet is considered a source of "new opportunities for journalists", offering unlimited possibilities for enhancing journalistic enterprise, while the "pessimistic" view blames new media technologies bringing about a breed of journalism practitioners with stunted creativity because of a new 'copy and paste culture'.

These binary perspectives mask nuanced shifts in journalistic routines, news values and ethical practices that are embedded within the social, political and economic environments in which these the new media technologies are deployed and appropriated. Thus, earlier studies have been less curious about how journalists perceive shifts in journalistic ethical practices in the context of new media technologies, and how these shifts are intricately interwoven with the socio-political and economic environment in which journalists operate. Castells (cited by Ndlela, 2008: 2) notes that:

We know that technology per se is not the cause of the work arrangements to be found in the work place. Management decisions, systems of industrial relations, cultural and institutional environments, and government policies are such fundamental sources of labour practices and production organizations that the impact of technology can only be understood in complex interaction within a system comprising all these elements 
This paper therefore examines ethical challenges and dilemmas faced by Zimbabwean journalism practitioners when using the internet, email and cellular phone in their day-to-day operations. In particular, the paper investigates how these new media technologies are impacting everyday journalistic practices and ethical practices among journalists who use the internet, email and cellular phone in their operations. It draws inspiration from Ward view that journalism ethics lacks a richer theoretical base and 'adequate epistemology', particularly one that explains practices in a multi-media environment (2008:304). Ward argues that journalism ethics too often falls back on simplistic appeals to general concepts such as "truth-seeking", "freedom", "serving the public" and "democracy", terms which are highly contested. The article makes attempts attempt to broaden pathways for theorizing journalism ethics by focusing on how journalists perceive challenges posed by the new media and how these challenges and dilemmas as are circumscribed by conditions in which journalism is practiced. The theoretical approach canvassed here is one that seeks to elaborate our understanding of how ethical practices are interwoven with technological, socio-political and economic conditions in which journalism is practiced.

Such an approach will help us understand better the conditions in which journalism ethics are being restructured by the tidal wave of technological innovations. Earlier studies have investigated the impact of new media from different angles using different methods (Friend and Singer, 2007, Pavlik, 1996, Pavlik 2001, Ward, 2008, Fulton,2008, Yau and AlHawamdeh, 2001 ,Gurleyen and Emre. 2010, Bastos et al, 2010, Berger, 2007, Ndlela, 2008, Mabweazara, 2010, Moyo, 2007, Chari 2009). However, in Africa research on the impact of new media technology on journalism practice in general and on journalism ethics in particular is scant, fragmented and practically there are no known studies on new media and journalism ethics on Zimbabwe. The few studies available (Berger, 1997, Berger, 2005, Moyo, 2007 Mabweazara, 2010), do not focus on how the use of new media technologies influence on journalism ethics per se.

This paper attempts to generate initial data and to initiate academic discourse on the subject by investigating Zimbabwean journalists' perceptions of the ethical challenges posed by the internet, email and cellular phone. The paper addresses two key questions, namely: What ethical challenges and dilemmas do journalists perceive in the use of the internet, email and cellular phones? What are the implications of these technologies on journalism practice? 
Although the term "new media technologies" is a "catch-all term" referring to a wide variety of web related communication technologies such as blogs, wikis, social networking and other social media (Friedman \& Friedman, 2008). In this article new media is used loosely to refer to email, the internet and cellular phone. The article also takes cognizance of fact that the "newness" of these technologies is an issue that is highly contested' (Lister et al., 2003, Silverstone, 2009; Ofuafor, 2009; Mabweazara, 2009), but does not wish to engage any further on the issue since it deserves a separate study.

\section{Towards a Sociology of Journalism Ethics}

Ward (2008: 137) defines ethics as "the analysis of conduct responsible practice and fair human interactions in the light of the best available principles". Ward adds that ethics is about practical judgment and the application of principles and the application of principles to issues and decisions. Journalism ethics thus encompasses a range of practical and theoretical decisions made by journalists during the news gathering, production and dissemination process. McNair (1998: 65) journalism is presented to its discourse as a "truthful discourse: about the real world and for it to command legitimacy it must be practiced ethically. Practicing journalism ethically as therefore a device for "constructing legitimacy" and to mobilize the trust of the audience. The fragmentation of theory around journalism ethics this article motivates for a sociology of journalism ethics which locates journalism ethics within the organizational context. While organizational approaches of media sociologists focus on the constraints imposed on journalism practitioners by the routine professional (McNair, 1994:50) the sociology of journalism ethics should focus on how the ethical behaviour, practices and attitudes are structured and shaped by are variety of organizational and external determinants. Thus, journalism products are regarded as a function of the organizational structure and routine bureaucratic problems such as limits on space and time. These routines also determine how news is prioritized in terms of time and space. McNair (1994:50) notes that:

The availability of space, according to this perspective is a basic organizational factor which may explain better than any presumption of bias why a certain newsworthy item is absent from a news programme or newspaper.

McNair (1998:64) argues that journalism reflects and embodies the historical processes within which it is developed and contemporary social conditions in which it is made. This means that 
the way journalists perceive ethics is influenced by the social circumstances in which they operate. Integrating the sociology of journalism and ethics enables us to widen the conceptual base of journalism ethics. If we acknowledge that ethical values are a by-product of social history the link between journalism ethics and new communication technologies becomes clearer. McNair (1998:67) notes how the search for objective truth was encouraged by the invention of photography, a medium with unprecedented "denotative accuracy and apparent truthfulness". The sociology of journalism ethics therefore enables us to understand how journalism ethics is intricately interwoven with socio-historical processes. While the product of journalistic work and the structural, organizational and external forces that shape have been subject to academic inquiry (see McNair, 1994, McNair, 1998, Dicknson, 2007) studies that locate journalism ethics in a sociological paradigm are non-existent. This is the reason why the present study finds merit in pursuing a sociology of journalism ethics. Such an approach will help us to have a better appreciation of forces located within and without the organizational context constrain journalists from practicing ethical journalism. While there has been considerable attention on evolving journalistic practices in the context of a changing technological environment very little research has been directed at ethical practices. Dickinson (2007:190) argues that:

There is...a rather more profound reason to be curious about how contemporary journalists do their job. No doubt for reasons of occupational self-interest, but perhaps also for reasons of loyalty, journalists themselves report only the most extreme examples of their colleagues' misconduct and it is unusual for news organizations to correct their errors or to examine them in detail. When they do allow themselves to reflect publicly on mistakes and malpractice journalists are apt to be philosophical.

We hope that integrating journalism sociology and journalism ethics will help chart new theoretical paths on important aspects of journalistic decisions, including ethical decisions, to such an extent that we can begin to talk about 'a sociology of journalism ethics', which may help us understand better the intricacies, of ethical decision making in media organizations. A sociology of journalism ethics should also help us understand better the conditions in which journalism ethics are evolving and the multiple causes that shape such evolution rather than relying on a simplistic mono-causal factor. A sociology of journalism ethics is urgent and imperative not only least because the poverty of theory in the field, but also because the 
boundaries of ethics are shifting as a consequence of the technological revolution. Furthermore, journalism plays an important role in producing public knowledge. The quality of information from the media and its social utility is predicated on its credibility.

\section{New Media and Journalistic Practice}

Recent studies on the interplay between new media and journalism practice are largely grounded on the technological determinism theory whereby technology is viewed as a driver of social change. This approach attributes changes in journalistic practices to technological innovations. Thus, technology is either lauded for ushering unlimited opportunities to the journalism profession or blamed for various negative ramifications on the quality of media products (Wasserman, 2001, Fulton, 2008, Yau and Al-Hawamdeh, 2001).

Deuze (cited by Batos and Moutinho, 2009:2) identifies three ways in which the Internet has transformed the journalism profession. The first is its enhancement of democratic culture, the second is the vast array of resources and technological possibilities it offers and the third is that, it brings about a new type of journalism - online journalism, which allows citizens to interact amongst themselves and with their governors.

An ethnographic study in Australia by Fulton (2008) revealed that journalists identify both negative and effects of new communication technologies on their work, but the majority felt that the new technology has more positives than negatives. Viewing the impact of new technology on journalism practice as either having "negatives" or "positives" is problematic because it masks the complex interplay of forces that shape journalistic practices. Some scholars argue that journalism practice takes place within certain institutional settings and organizational structures, where decisions are made and production processes prevail (Ndlela, 2008). All these factors must be taken into account if we are to fully understand the impact of technology on journalism practice.

Gurleyen and Emre (2010), studied how Turkish journalist bloggers (j-bloggers) negotiate traditional norms of journalism such as objectivity or practices like gate-keeping. They found that most journalist bloggers prefer to operate within the bounds and norms of traditional journalism. The study brings out important insights on the interface between journalist bloggers and traditional journalists although it did not specifically focus on ethical practices 
and challenges. The assumption that journalists bloggers should explore "the liberating" potentials offered by the new medium echoes the technological deterministic tone of earlier studies, whereby journalists are viewed as silos of knowledge in society. Such an approach does not help much in unpacking the way in which new journalists interact with new technology.

Most studies that have explored the impact of new media technologies on journalism practice are based on the experiences of media saturated countries of the West. (Arant,2000; Bradely, 2001; Shumway and Berkman, 2001; Singer. 2001). These studies tend to focus more on ethical dilemmas posed new media technologies on online journalism. As a result, the impact of new media technologies on traditional media, particularly in Africa remains anecdotal.

This article attempts to generate initial data on the impact of the Internet, email and cellular phone on journalism ethics, focusing on the experiences of Zimbabwean journalists. The paper acknowledges the existence of snippets of literature relating to new media and journalism on the African continent (Berger, 2005, Mabweazara, 2005, Mabweazara, 2010, Moyo, 2007). A book edited by Guy Berger (2005) is perhaps one of the first attempts to investigate the use of Information Communication Technologies (ICTs) (the internet, email and cellular phones) in selected newsrooms in nine Southern African countries. The study investigated the various problems embedded in the use of ICTs (Berger, 2005:8). Internet use was found to vary across countries, but email was used by all respondents. The study found that there was extensive utilization of ICTs and a considerable number of journalism practitioners confessed that they had engaged in some unethical practices, such as lifting material from the internet without attribution or downloading pornographic material (Letlhogile, 2005:35). Mabweazara (2005:96) notes that Zimbabwean journalists who participated in the study refuted the existence of plagiarism among themselves. The study did not specifically delve into the issue of ethical challenges and dilemmas as it was more concerned with the diffusion and use of digital technologies and newsroom practices in a changing environment. As a result very little is known about ethical implications of new media technologies on newsgathering and dissemination in Zimbabwe.

The situation in the Zimbabwean newsrooms has phenomenally changed since 2005, when the study referred to above was conducted. Internet and cellular phone use have dramatically 
improved nationally and in the newsroom. Whereas the cell phone and Internet were status symbols in 2005, in 2012 there is hardly a journalist in the newsroom who does not use these technologies to gather news. There are compelling reasons to conduct an investigation of this nature in order to help understand the implications of the Internet, email and cellular phone on ethical practices among the country's journalism practitioners. Informed by the foregoing theoretical framework and literature this article examines the ethical challenges and dilemmas faced by Zimbabwean journalists through the use of new communication technologies, and how this impacts on the quality of news and information.

\section{Methodological Considerations}

The study combined a descriptive survey and semi-structured interviews to investigate the journalism ethics and dilemmas faced by Zimbabwean journalists and their impact on the quality of news and information. The survey was mainly used to gather data on perceptions of Zimbabwean journalists of ethical dilemmas and challenges they face when using the Internet, email and cellular phones in their newsgathering operations. Scholars argue that the survey method is more efficient when investigating problems in realistic settings or collecting large amount of data than other methods (Wimmer and Dominick, 1983). The target population for the study was all practicing journalists in the print and broadcasting industry who were based in Zimbabwe at the time of the study. Purposive sampling was used to select respondents because of the difficulty of accessing subjects who are scattered throughout the country. Forty (40) questionnaires were distributed to practicing journalists in Harare. Efforts were made to ensure that the sample was representative of gender, media type and ownership. The questionnaire consisted of fifteen (15) questions, thirteen of which were open ended and two (2) closed-ended. Thirty-four (34) questionnaires were successfully completed giving a return rate of eighty-five (85\%). Although purposive sampling has been criticized for being biased, the relatively small number of practicing journalists in the country at the time, and the scattered nature of their operations throughout the country made purposive sampling procedure more suitable (Silverman, 2005:129). In order to validate data from the survey and also to be able bring out nuances which could not be gleaned through a questionnaire, semistructured interviews were conducted with 10 different journalists. The interviews took place in the capital city of Zimbabwe, Harare, between the $5^{\text {th }}$ and $8^{\text {th }}$ July 2010 . Notes from the semi-structured interviews were transcribed, coded into themes and analyzed using 
hermeneutic interpretation. Data from the survey was analyzed using Osgood, Succi and Tannenbaum (1957)'s semantic scales and presented in tables.

\section{Demographic Data}

Sixty-eight percent (68\%) of the respondents were male, while thirty-two percent (32\%) were female. Ninety-one percent $(91 \%)$ of them were employed in the print media, while nine percent $(9 \%)$ were employed in the broadcasting industry. The average respondent was a holder of a college diploma, with the youngest (20 - 25) constituting forty-one percent (41\%), while the oldest (40 plus) constituted twelve percent (12\%) of the respondents. Respondents had an average working experience of six years.

\section{New Communication Technologies and Unethical Practices}

A key objective of this article was to examine the ethical challenges and dilemmas confronted by Zimbabwean journalists as a result of new communication technologies, such as email, Internet and the cellular phone. Question B4 of the survey questionnaire asked respondents whether they felt the Internet, email and the cell phone had contributed to certain ethical dilemmas and problems in Zimbabwe. Table 1 below shows what Zimbabwean journalists perceive as common ethical problems in the country.

Table 1: Most prevalent unethical practices in Zimbabwean media

\begin{tabular}{|l|c|c|}
\hline \multicolumn{1}{|c|}{ Unethical Practice } & Yes \% & No \% \\
\hline - Plagiarism & 97 & 3 \\
- Use of anonymous sources & 88 & 12 \\
- Gossip & 82 & 18 \\
- Hate speech & 82 & 18 \\
- Dissemination and consumption of pornography & 76 & 18 \\
- Sensationalism & 76 & 24 \\
- Invasion of privacy & 74 & 24 \\
- Falsehood & 74 & 26 \\
- Manipulation of photography & & \\
\hline
\end{tabular}


Table 1 above indicates that the majority of the respondents (97\%) feel that the internet has contributed to plagiarism compared to $3 \%$ who feel that the internet has not done so. In addition to plagiarism, the use of anonymous sources is perceived by eighty-eight percent $(88 \%)$ of the respondents to be another serious unethical practice that has increased due to the internet, while $12 \%$ disagree. Gossip, hate speech and dissemination and consumption of pornography are also other unethical practices that are perceived to be linked to the new communication technologies, such as the internet. Respondents were also asked to affirm or decline if they knew someone who had engaged in some unethical practices in the past (question no. 9). Table 2 below shows the responses to this question.

Table 2: I know someone who has engaged in this unethical practice

\begin{tabular}{|l|c|c|}
\hline Unethical Practice & YES (\%) & NO (\%) \\
\hline Plagiarized stories from the internet & 74 & 26 \\
Used non-existent sources & 71 & 29 \\
Disseminated pornography through the cellular phone & 59 & 41 \\
Plagiarized stories from foreign news agencies & 44 & 56 \\
\hline
\end{tabular}

Table 2 above shows that plagiarism, the use of non-existent sources and the dissemination of pornography through the cell-phone are the most serious unethical practices that have come about as a result of the use of new communication technologies. Seventy-four percent (74\%) of the respondents affirmed that they know someone who has plagiarized stories from the internet compared to $25 \%$ who said they did not know anyone who had engaged in this unethical practice. Respondents were also asked to name what they think is the most serious unethical practice in Zimbabwean journalism.

Table 3 below shows the seriousness of unethical practices as perceived by Zimbabwean journalists.

Table 3: The most serious unethical practice among Zimbabwean journalists.

\begin{tabular}{|l|l|}
\hline Unethical practice & $\%$ \\
\hline Plagiarism & 26 \\
\hline Use of anonymous sources & 24 \\
\hline Gossip & 21 \\
\hline
\end{tabular}




\begin{tabular}{|l|l|}
\hline Falsehoods & 10 \\
\hline Sensationalism & 9 \\
\hline Invasion of privacy & 5 \\
\hline Hate speech & 3 \\
\hline Dissemination and Consumption of pornography & 1 \\
\hline Manipulation of photography & 1 \\
\hline Total & 100 \\
\hline
\end{tabular}

Table 3 above shows that the most serious unethical practices among Zimbabwean journalists are plagiarism (26\%), use of anonymous sources (24\%), gossip, (21\%), falsehoods (15\%) and the least serious is the manipulation of photography $(1 \%)$.

Findings from interviews also corroborate the survey results, particularly what is generally perceived to be the most prevalent unethical practices. Plagiarism, use of anonymous sources and gossip were frequently mentioned as the major unethical problems associated with the use of cell phones and email. The dependence of journalists on new media for sourcing news destroys creativity and undermines the culture of rigor associated with traditional journalism. Some journalists interviewed expressed concerned about 'sedentary journalistic practice" because of new communication technologies which enable them to gather news from their desks. One respondent said journalism was becoming more of "an armchair" profession because of the internet, email and cellular phone. What is instructive is that these fears were expressed even by respondents who were overly positive about the new media technologies.

Thus the Internet, email and the cellular phone were reconfiguring reporter-source relationships in a profound way. Because journalists no longer ventured outside the newsroom like they used to do before the introduction of the Internet, email and cellular phone the bond between them and their sources was loosening. There is diminishing personal contact between journalists and their news sources thereby raising fears that in the long run news might become too artificial because journalists no longer have enough time to probe into issues in a robust manner.

One respondent claimed that he knew of some colleagues who 'simulate interviews' when they fail to reach sources through the phone because of pressure of deadlines. Berkowitz and 
TerKeurst (1999:125) characterize the relationship between journalists and their sources as situated within the social context of communities (interpretative communities), where shared meanings develop through on-going social interaction. Berkowitz and TerKeurst (1999:125) argue that the relationship between journalists and news sources is shaped by the preferred meanings of the community's interpretative groups, including journalists and their news organizations.

\section{Ethical Practices and Gender}

Perceptions about the seriousness of ethical problems differ significantly across gender lines. For instance, $73 \%$ of the female respondents perceive the "lifting of copy from the internet without proper acknowledgement" to be either serious or very serious, compared to $62 \%$ of the male respondents who perceive the same practice to be either serious of very serious. A significant percent of female respondents i.e. $82 \%$ compared to $65 \%$ male respondents perceive "lifting of copy from the internet without proper acknowledgement without proper acknowledgement".

The difference in perceptions about the seriousness of unethical problems is not easy to figure out, the extent to which journalists use news from online news sources appears to be more plausible. Significantly, $56 \%$ of the female respondents described the use of stories from other news agencies as "heavy" compared to $3 \%$ male respondents who described the use of stories from other news agencies as heavy. It is possible that the reasons for these differences lie in nuanced newsroom practices chalked by organizational power relations. It would appear that female journalists most of whom cover soft beats such as entertainment, health, cookery etc, are prone to plagiarism than their male counter parts because they rely on 'ready-made' information, which increase chances of plagiarism their male counterparts who cover 'hard beats' like politics and business that require fresh perspectives that take them out of the newsroom.

This shows that ethical issues are intertwined with complex socio-cultural and organizational practices. However, to be able to establish such causal conclusively further research is needed. 


\section{Ethical Practices According to Media Type}

Perceptions of ethical problems also vary considerably between print media journalists, and their broadcasting counterparts. For instance, $96 \%$ of print media journalists perceive plagiarism to be a very serious problem in the country, compared to $60 \%$ of the broadcast journalists who view plagiarism to be very serious. Furthermore $85 \%$ of the print media journalists think that the use of anonymous sources is a very serious problem in the country, compared to 52 broadcast journalists who share a similar view. There is more competition in the deregulated print media sector in Zimbabwe, compared to the broadcasting sector which enjoys monopoly. Print media journalist also face fierce competition from online publications and websites operated by Zimbabweans in the Diaspora. As a result they are prone to unethical practices than their counterparts in the broadcasting sector. Online news websites have more latitude to publish without verifying stories because they operate outside the perimeter of stringent media laws such as the Access to Information and Protection of Privacy Act (AIPPA). One respondent said that, the fear of being 'scooped' by online news media has put print media journalists in a very difficult position, in the sense that any delay in publishing a story means losing it to an online publication. Because online publication correspondents use pseudonyms they are not afraid political persecution or their reputation. The view that the print media is amenable to unethical practices is corroborated by a statement from a respondent who had this to say:

As for broadcasting, maybe it (new media technology) has little effects, but print, yes. Journalists can do whatever they deem necessary so that they produce a story (sic). Angness, Print Media Reporter.

Stiff forces print journalists, to take "a plunge into the abyss, thereby sacrificing professional ethics at the altar of commercial expedience", as one respondent put it. Apart from commercial pressure, broadcast media production tends to be more centralized than print. Print media journalists enjoy more autonomy than their broadcast counterparts whose stories are more 'institutionalized', and therefore subjected to rigorous gate-keeping processes. Coincidentally, all the high profile cases of plagiarism that have been publicized in the country over years involved print media journalists. It could also be argued that these incidences of unethical practices might have influenced print media journalists' to exaggerate the seriousness of ethical problems in the country. 
It is worth noting that ethical practices are interwoven with numerous organizational, cultural, social and structural practices such that a clear causal link between new media technologies and the perceived ethical problems is difficult to establish. For instance, one could argue that business considerations or the imperative to make profit rather than technology dictates the pace for journalists to operate at a 'supersonic speed', thereby negating professional ethics. A respondent had this to say in this regard: 'There is now real competition among journalism practitioners, with these technologies one can easily overtake you and publish the same story within hours, so practitioners are always on the lookout for scoops and exclusives' supports the point being made here. This shows that new communication technologies redefine ethical challenges and dilemmas faced by journalists as well as well as bringing about new ones.

\section{Ethical Problems and Work Experience}

Perceptions of ethical problems differ significantly between more experienced and less experience journalists. More experienced journalists tend to view unethical practices among Zimbabwean journalists as less grave than those who are less experienced. For instance, only $35 \%$ less experienced journalists view 'overreliance on foreign news agency copy' as either serious or very serious, compared to $44 \%$ of more experience journalists who share a similar view.

Again, 35\% of more experienced journalists perceive the 'extensive use of quotations from internet sources', as serious or very serious, compared to $50 \%$ less experienced journalists who view this problem in similar light. In addition, $81 \%$ less experienced journalists view the 'use of non-existent sources' as serious or very serious, compared to $76 \%$ more experienced journalists who share a similar view. The likely explanation for this could be that, more experienced journalists are better equipped to handle ethical dilemmas than less experienced ones. Experienced journalists are more creative than junior ones who are on the learning curve. Journalism, being more of a routine job means that those who have many years experience are more schooled in the ethics of the profession than those who have just joined. In addition, experienced journalists have established a network of sources such that it is highly improbable that they cannot run out of sources for any particular assignment. 
From another angle, it could be argued that these differences in perceptions of ethical problems reflect the differences in attitudes towards new media technologies between the 'old guard' and entry-level, youthful journalists. Youthful journalists are attuned to view new media technologies less problematically than veteran journalists who started working before these technologies received widespread acceptance. Some of the statements by youthful journalists point to this and suggest that youthful journalists view new media technologies as unleashing unlimited opportunities for the journalism profession. The following statements from some respondents buttress this point:

I don't know how the old generation used to do it. I guess it was a nightmare for them. As for me I am lucky enough (sic) to have started working when these media technologies were already in place. John, Age 24, Broadcast media.

I only started working three years ago and these technologies were already there. But I have always wondered how the 'old school' used to operate. I am sure it must have been hell working without a cell phone or email. Takura 23 Print Media.

These sentiments suggest that youthful journalists rely more on new media technologies and therefore are vulnerable to unethical practices which are enhanced by these technologies. However, further investigations still need to be done around this matter since there is a complex web of environmental factors involved. It would be shortsighted to single out new technology as the determinant of ethical problems.

\section{The Contradictory Impact of New Communication Technologies on Journalism Ethics}

Data from the study shows that new communication technologies have also both a positive and negative impact on journalism ethics. The nature and degree of influence depends on the type of technology. Most respondents interviewed for this study tended to emphasize the technical enhancements brought by the Internet, such as the ability to cross-check and verify facts, thereby enhancing balance, accuracy and objectivity of news. The fact that Internet enables journalists to do background research ensures that stories are complete and free of factual errors. One respondent had this to say: 
The Internet helps me ensure that my stories are free of factual errors. If I am doing a story about a certain personality in the entertainment industry, and I am not sure about the name of their first album or the year they released their first album I just log on to the internet, rather than wasting time going to the archives (Tamuka, print media entertainment reporter).

The down side of this is however, that because of its anonymity, the internet creates opportunities plagiarism. Plagiarism takes several forms, but the main ones are lifting text from parts of a story without acknowledgement or taking someone's story ideas and adapt them to the local context. The following statements are illustrative:

- If I am under pressure I can just copy and paste without acknowledging my sources. Ricky, Print Media

- I know some people who visit some unfamiliar websites and copy whole stories without acknowledging their sources. Tinotenda, Print Media.

One concern voiced by respondents, which is related to the issue of plagiarism, but has far reaching implications on traditional journalism ethics is the perception that the internet was replacing the culture of rigor associated with traditional journalism ethics with what most respondents described as 'arm chair journalism'. There was a general consensus that the internet promotes 'lazy journalism' because instead of venturing outside and interact with news sources, journalists were now relying on the internet. Some respondents pointed out the risk of producing what they described as a 'google journalist', i.e. one who relies on the internet for everything, resulting in them getting out of touch with real people.

While the ethical implications of these practices are not easy to pin down with precision, some sentiments from respondents suggest that fact-checking, accuracy and most importantly rigor, which are the hallmarks of traditional journalism ethics might be under threat. The following statements from some respondents are instructive:

- The internet promotes a culture of not digging deep, because everything is available, so scribes tend to information at hand, even if it is not factual. Joshua Broadcast Media. 
- I am fast losing touch with my list of reliable sources that I used to have before the advent of the internet. Eddson Broadcast Media.

- The internet has given room to fictitious and malicious stories. For example one person started a story that Gono was dead and it travelled like veldt fire on the internet. Tonderai Print Media.

Whatever influence on ethics is attributable to the internet one needs to be more nuanced because the adoption and use of technology is mediated by a host of factors, and commercial considerations are one of those. This is why it is instructive to note that most journalists who claim to have violated journalism ethics cite pressure of deadlines or lack of adequate time. This is because the prevailing logic of the media under the market system is dictated more by the profit making imperative than anything else. This is an issue which warrants a separate investigation.

Respondents also cited both positive and negative impacts of cellular phones on journalism ethics, but tended to accentuate the positives. However, tt took a bit of probing for them to mention the negatives. Although most of the positives about the cellular phone relate more to general journalistic practices one key aspect relating that was recurrent was the fact that the cellular phone has enhanced the ability of journalists to check and verify information before publishing, thus ensuring accuracy, balance, fairness, impartiality and completeness of stories. One respondent had this to say:

I am able to phone my sources to cross check facts, figures and names while I am doing the story. At the same time I can also give people concerned the right of reply so that I cover both sides of the story. There is no more excuses about people not be reachable 'at the time of going to press'. Patricia, Print Media.

However, some respondents were quick to point out the negative impact of the cellular phone on journalism ethics. One respondent talked of 'a bad habit' by some journalists who, when they are under pressure of deadlines fake interviews, whereby all their sources are either "highly placed sources who refused to speak on the record for professional reasons" or simply "an anonymous source close to this newspaper". Some respondents also spoke of increasing cases of colleagues who, because of pressure of work, or laziness publish a story without 
giving parties the right of reply on the false pretext that 'their cellular phone was on voicemail'. The gradual weakening of interpersonal relations between the journalist his or her sources and the resultant weakening bond between the two appears to be cultivating a liberal and permissive ethical culture, whereby not being reachable via the mobile phone is equated with 'not being available at all'

The other problematic issue concerning cellular phone is the issue of 'news tips' from anonymous members of the public. Respondents spoke of some of these 'news tips' have in the past turned out to be 'hoaxes' or mere rumours. One respondent had this to say:

Sometimes we receive news tips from members of the public via sms. There is always a compelling urge to publish at the earliest possible time, but more often we discover that such stories are based on hearsay. If you are afraid of losing a 'juicy’ story you may end up publishing it, only to discover that it was a rumour. An example is a story that has been doing the rounds that Gono (Gideon) ${ }^{1}$ has died. That story has travelled the whole world through the internet and yet it was just a rumour. That is how some newspapers end up publishing falsehoods and then retract them the next morning. Jeffrey, Print Journalism Reporter.

However, technology alone cannot be blamed for the erosion of traditional journalism ethics. An assessment of the real motives for not following proper ethical procedures (at least from what most respondents say) is that the decision whether to publish now or later is tied to commercial considerations. That is, "if we do not publish today because we cannot get hold of the people concerned the story will be taken by another publication that does not care about ethics', so goes the logic. Hence, our understanding of how new technology is shaping and reshaping journalism ethics requires that we look at the whole context in which journalism is practiced today, rather than focusing one aspect.

In terms of positives email is praised for having improved the quality of stories. Email enables journalists to contact long distance news sources, particularly those outside the country. This enables them to publish balanced and objective stories, the hallmark of ethical journalism. In terms of the negative implications of the email on journalism ethics respondents spoke mainly about the problem of 'public relations' emails from civil society and corporate organisations' 
who seek to influence the news agenda. One respondent spoke about how his newspaper, sometimes gets overwhelmed with press releases, via email from civic organizations who may want to set the agenda on particular stories, threatening the editorial independence of the newspaper.

Email was also undermined the transparency of journalism in the sense that both on the part of journalists and the audience. For instance, a respondent claimed that some members of the public use 'fake email accounts' to spew vitriol and hate speech in newspaper columns.

The polarized political environment in which journalism in is practiced in the country means that people hold entrenched positions and some use fake email accounts to vent pent up emotions towards certain individuals. One respondent claimed that he used to publish his email address in an opinion column in his newspaper but stopped doing so after he started getting 'negative feedback' in the form of abusive emails from newspaper readers. He had this to say:

The emails started coming thick and fast and my email box was clogged with vitriolic messages, directed at my person. Some hailed obscenities while others called me all sorts of names. Some threatened me, and advised me not to walk in the streets of Harare without a bodyguard. I then took a decision to remove my email address, closed the account but my column continued with renewed zeal. Fredrick, Print Media Line Editor.

The salutary lesson from this statement is that technology can be used by anyone, for anything, good or evil. Hence, when discussing the impact of technology on journalism ethics it is imperative to understand the whole gamut of factors in which it is adopted and used.

\section{Concluding Remarks}

This article has discussed perceptions of Zimbabwean journalists of the different ethical challenges associated with the internet, email and cellular phone. It was found most journalists perceive plagiarism, use of anonymous sources, gossip and hate speech as the most serious unethical practices associated with new media technologies. There is an indication that journalism practitioners are over-relying on new media technologies for gathering news. This 
tendency might in the long run negatively affect journalistic creativity and the vigour for which traditional journalism is renowned.

Findings also show that perceptions of the seriousness of these challenges differ across medium, work experience and gender. The observation is also in line with one made by Bastos et (2010:12) who noted that Portuguese journalists' perceptions of the influence of the internet on journalism practice varied according to age, gender and the newspaper they work for. This is instructive in the sense that it might be an indication that ethical issues are enmeshed in complex socio-cultural and organizational processes.

Another key observation made is that respondents in this study view new media technologies as having both negative and positive impacts on journalism ethics. This shows that technology has got a dialectical impact on journalism practice and journalism ethics and the actual way in which it impacts on journalistic practices is also complex. The argument advanced here is that a broader understanding of the way in which technology impacts on journalistic practices in general and ethics in particular we need to take into account the whole gamut of forces (internal and external) that affect a media organization.

We find Dickinson (2007:207)'s argument that unethical journalistic behaviour should be viewed against the backdrop of the organizational environment in which it is practiced more plausible. Hence, there is need to examine closely the organizational conditions and processes in which journalism is practiced in order for us to understand better the impact of new media technology on journalism ethics. This article therefore, canvasses a holistic approach that combines sociology of journalism, sociology of journalists and critical economic approaches to be able to appreciate the processes in which technology impacts on journalism ethics. Such an approach will enable us to build a more grounded theory of the 'sociology of journalism ethics'.

It is however important to point out that the sampling method used in this study makes it difficult to generalize findings in this study since the study only covered journalists in the capital of the country, Harare. A more representative study, employing incorporating ethnographic approaches could yield more conclusive findings. Other potentially fascinating areas of investigation could be a comparative assessment of the perceptions of online 
journalists and traditional media journalists' of ethical challenges and dilemmas, or examining how perceptions of ethical challenges differ across different newspapers (i.e. daily newspaper journalists vs. weekly newspaper journalists, or broadcasting vs. print etc). 


\section{References}

Arant, D. (2008). 'Online Media Ethics: A survey of US daily newspaper editors'. Paper Presented at the Association for Education in Journalism and Mass Communication Convention, Phoenix, August, 2000. [Online] http://www.factstaff.elon.edu.anders/onlinesurvey.html. Accessed, 9 May, 2008.

Bastos, H., Lima, H. \& Moutinho, N. (2010), The influence of the internet on Portuguese press, retrieved on 20 October, 2010 from htto://aleph.letras.up.pt/exlibris.aleph/a18_1apache_media/NMALINLKV1S7QNIRE DSQMR3I34R2DN8.pdfBatos

Berger, G. (ed.), (2005). Doing Digital Journalism: How Southern African Newsgatherers are Using ICT. Grahamstown: Rhodes University.

Berger, G. (1997). 'Harnessing Information Technology for Africa’s Independent Media: Plant the Crops at the Start of the Rainy Season'. Conference on Sustainability of Independent Media in Southern Africa, the Media Institute of Southern Africa (MISA), Victoria Falls, [Online] http://wwwjourn/staff/berger-miat.html Accessed 12 August, 2008.

Berkman, R. I \& Shumway, C. (2003). Digital Dilemmas: Ethical issues for Online Media Professionals. London: Blackwell Publishing.

Berkowits, D. \& TerKeurst, J., (1999). 'Community as Interpretative Community: Rethinking the Journalist-Source Relationship'. Journal of Communication, (49), pp125-136.

Chari, T.J., (2009), 'Ethical Challenges facing Zimbabwean media in the context of the internet'. Global Media Journal, African Edition, Vol 3 (1) [Online] http://sun025.sun.ac.za/portal/page/portal/Arts/Departemente1/Joernalistiek/Global\%2 0Media\%20Journal/Global\%20Media\%20Journal\%20\%20Files/8C985F826DA95119 E04400144F47F004, Accessed, 15 May 2010.

Dickninson, R. (2007) Towards a Sociology of Media Occupation: Cultural Sociology, July 2007 (1), pp189-208.

Friedman, L.W., \& Friedman, H.H., (2008) The New Media Technologies: An Overview and Research Framework. Social Science Research Network. Retrieved from http://papers.ssrn.com/sol3/papers.cfm?abstract_id=1116771 on 13 February 2012.

Friend, C. \& Singer J.B. (2007) Online Journalism: Traditions and Transitions. London: M.E. Sharpe 
Fulton, J. (2008) Print Journalism and the creative process: traditional versus digital. Paper Presented at the Conference on Comparative Journalism Studies, Hobart Tasmania: University of Tasmania, Retrieved October 29, 2010 from http://www.utas.edu.au/ejel/journalismstudies/documents/CJS08\%20Fulton\%20revise d\%20paper.pdf

Gordon, D.A., \& Kittross, J .M., (1999). Controversies in Media Ethics. London: Longman. Gurleyen, P. \& Emre, P.O. (2010) Exploring new journalistic platforms: experiences of Turkish Journalist bloggers' retrieved on 13 October 2010 from http://online.journalism.utex.edu/2010/papers/PinarPerrin10.pdfPinarGurleyenPhD.Student in Simon Frazer University-Canada. Perrin Ogun Emre, Phd. Candidate, Marmara University,-Turkey also lectuter in Kadir Has University-Instabul, Turkey. Ikpe, E.,H., \& Olise, F.P., (2010) The Era of New Media Technologies and the Challenges of Media Relations Practice in Nigeria. Journal of Communication, Vol. 1., No. 2., pp 5968.

Kabwato, C., (2005). 'TANZANIA', In Guy Berger,(ed.), Doing Digital Journalism: How Southern African Newsgatherers are Using IC. Grahamstown: Rhodes University.

Kim, D., \& Johnson, T.J. (2009). 'A shift in Media Credibility: Comparing Internet and Traditional News Sources in South Korea', International Communication Gazette, Vol.71(4): 283-302.

Lasica, J. D., (1997). 'Preserving Old Ethics in a New Medium', American Journalism Review, December, [Online] http://www.ajr.org/articles.asp.,Accessed, 3 March 2008. Letihlogile, L., (2005). 'BOTSWANA', In Guy Berger, (ed), Doing Digital Journalism: How Southern African Newsgatherers are Using ICT. Grahamstown: Rhodes University, Mabweazara, H., 2005. 'ZIMBABWE' Guy Berger, (ed), Doing Digital Journalism: How Southern African Newsgatherers are Using ICT, Grahamstown, Rhodes University, Mabweazara, H.M., 2009. 'New' technologies and Journalism practice in Africa: Towards a critical sociological approach' [Online] researchrepository.napier.ac.uk/.../Hayes_Mabweazara_Final_Draft_Chapter.doc, Accessed, 25 August, 2010.

Lister, M., Dovey, J., Giddings, S., Grant, I., \& Kelly, K., (2003). New Media: A Critical Introduction. London: Routledge.

McNair, B. (1994) News and Journalism in the United Kingdom. London: Routledge. McNair, B., (1998) The Sociology of Journalism. London: Arnold. 
McQuail, D. (2010) Mass Communication Theory. London: Sage.

Merrill, J. (1999). 'Foundations for Media Ethics', In David A Gordon, \& John Micheal Kittross, J.M.. (eds.) Controversies in Media Ethics. London: Longman.

Mingzin, Z. (2006). The present situation and analysis of mass media use and credibility the countryside of mid-China: The case of Hubei Province in China. In Media Research, 2 (4):pp37-47

Moyo, D., (2007). 'Alternative Media Diasporas and the mediation of the Zimbabwean Crisis', Ecquid Novi: African Journalism Studies, Vol. 28 (1\&2) pp81-105.

Ndlela, N.M. (2008), 'Journalism practice and the dynamics of change in Norway', Paper presented at the Nordic Media Theory Conference, Reuters Institute for the Study of Journalism and Oxford University, Department of Scandinavian Studies, Oxford,7-8 November. Retrieved on the $23^{\text {rd }}$ of October 2010 from http://www. reutersinstitute.politics.ox.ac.uk/fileadmin/documents/nordic.../Ndela.doc

Ndlovu, R., (2009). 'Bridging the Digital Divide: Sound ICT policy vital'. The Zimbabwean, 16 April, 2009.

Ofuafor, M., (2009). The Influence of "New Media" forms on Media Reportage and Democracy in Nigeria, Paper Presented at the Media and Democracy Conference, 5-8 July, 2010, Accra, Ghana.

Pavlik, J. (1996) New Media Technologies: Boston: Allyn and Bacon.

Pavlik, J. (2001) Journalism and New Media. New York: Columbia University Press. Pindayi, B., 2010. 'Framing of the 2008 Cholera Crisis in two Zimbabwean Weeklies, Unpublished MA Dissertation. Harare, English and Media Studies Department, University of Zimbabwe.

Silverman, D. (2005). Doing Qualitative Research. London: Sage Publications.

Silverstone, R. (1999). What's New about New Media?, New Media and Society.1(1): pp1012

Singer (2001). The Daily News, 2002. 'Woman's body not found', 27 April, 2002. The Zimbabwean Diaspora, 2010. 'Gono death report false' June, 26, 2010, [Online], http:www.thezimbabwean.co.uk/index.php? option=com_content\&view=article\&id=3213 Accessed 10 August, 2010.

Ward, S. (2008) Journalism Ethics, in Karin Wahl-Jorgensen and Thomas Hanitzsch (ed) The Handbook of Journalism Studies. London: Taylor and Francis. 
Ward, S., (2008) Global Journalism Ethics: Widening the Conceptual Base. Global Media Journal, Canadian edition. Vol. 1 No. 1, pp137-149.

Wasserman, E. (2010) Threats to Ethical Journalism in the New Media Age, Media Ethics Online, Vol.21, No.2 retrieved on 13 October 2010, from http://media.www.mediaethicsmagazine.com/media/storage/paper655/news/2010/07/0 1/AnalysesCommentary/Spring.2010.Vol.21.No.2threats.To.Ethical.Journalism.In.The .New.Media.Age-3919175.shtml

Wimmer, R. D. \& Dommick, J. R., 1983. Mass Media Research. California: Wadsworth Publishing Company.

Yau T.J. \& Al-Hawamdeh (2001) The impact of the internet on Teaching and Practicing Journalism, Journal of Electronic Publishing, Vol.7, No.1. August 2001.

ZIMEYE 2010. 'Gideon Gono dies' June, 26, 2010, [Online] http://wwwnewzimsituation.com/5415k2/breaking-news-gideon-gono-dies-htm, Accessed, 12 August, 2010.

ZWNews 2002. 'Mugabe backlash fear over misleading story' February 12, 2002. [Online] http://wwwzwnews.com/issueful.cfm, Accessed, October, 18, 2006, Originally appeared in The Daily Telegraph (UK) February, 12, 2002.

\section{Acknowledgement}

I would like to thank Problem Masawu who assisted with some of the interviews in Harare.

\footnotetext{
${ }^{1}$ The Governor of the Reserve Bank of Zimbabwe.
} 